\title{
Availability of adequately iodized salt at household level in Dessie and Combolcha Towns, South Wollo, Ethiopia
}

\author{
Tefera Chane Mekonnen ${ }^{*^{*}}$, Sisay Eshete ${ }^{1}$, Yitbarek Wasihun ${ }^{2}$, Mastewal Arefaynie $^{3}$ and Nigus Cherie $^{3}$
}

\begin{abstract}
Background: lodine deficiency disorder is the leading cause of mental retardation and poor economic performance in developing countries. Worldwide, universal salt iodization has been implemented to eliminate iodine deficiency. However, the adequacy of iodine in salts needs close monitoring to meet its intended goal and this study was aimed at investigating the adequacy of iodine in dietary salt at household level in Dessie and Combolcha Towns.

Methods: A community-based cross-sectional study was employed at household level in Dessie and Combolcha towns from January to February, 2017. Data were collected from 753 households using systematic sampling technique. The adequacy of iodine in salt was analyzed using rapid testing kit. Socio-demographic and economic, dietary sources, labeling, packaging, storage and cooking methods of household's characteristics were collected via questionnaire developed using open data kit tool and STATA version 12 was used for further statistical analysis. Ordinal Logistic regression was performed to assess associations between explanatory variables and the response variable.

Results: Nearly one-thrid (31.2\%) of the households used inadequate iodized salt, which was below the World Health Organization recommendation level ( $\geq 15 \mathrm{ppm}$ at the household level). Most of the respondents from Combolcha town (64.6\%) were affected by inadequate use of iodized salt as compared to Dessie Town residents (22.2\%). Being Dessie resident $(\mathrm{OR}=2.53 ; 95 \% \mathrm{Cl}: 1.31-4.90)$, households with better socioeconomic status $(\mathrm{OR}=2.54 ; 95 \% \mathrm{Cl}: 1.10-5.87)$, site of labeling and packing (salt from open market ( $\mathrm{OR}=0.10$; $95 \% \mathrm{Cl}: 0.04-0.23)$ and no exposure to sunlight $(\mathrm{OR}=2.54 ; 95 \% \mathrm{Cl}$ : 1.31-4.91) were the predictors of adequacy of iodized salt at household level.
\end{abstract}

Conclusions: Availability of adequately iodized salt at the household level in the study area was low. There should be regular quality control and regulatory enforcement of salt iodization at production, labeling and packaging sites of small scale industries and at household level.

Keywords: Adequacy, lodized salt, Household level, Dessie, Combolcha, Ethiopia

\section{Background}

Iodine is an essential element for normal function of the thyroid gland. Its deficiency is the most common cause of preventable mental retardation and brain damage in the world [1-3]. Iodine deficiency disorders (IDD) is manifested in multiple adverse health consequences like decreased child survival rates, goitre, abortion, stillbirth, malformation and overall impaired growth and development $[1,4,5]$ and remained major public health

\footnotetext{
* Correspondence: teferachane@gmail.com

${ }^{1}$ Human Nutrition Unit, Department of Public Health, Wollo University,

Dessie, Ethiopia

Full list of author information is available at the end of the article
}

challenge and an obstacle to economic development worldwide $[6,7]$. Iodine deficiency remains a public-health problem in many low-income countries, and more than a billion individuals consumed an insufficient dietary iodine [8]. Reports revealed that 38 million children born every year are at risk of brain damage because of iodine deficiency [9].

In Ethiopia, around 28 million people suffer from goitre, and more than 35 million people are at risk of iodine deficiency. More importantly, 50,000 perinatal deaths are related to iodine deficiency each year in Ethiopia. The education potential of the nation is unattained as iodine deficiency may cause an intelligence quotient reduction of 13.5 points [9]. The problem is both a threat 
to the productivity of the workforce and a cause of cretinism and mental retardation which lead to an enormous loss of gross domestic product [10].

WHO recommends a daily intake of $90 \mu \mathrm{g}$ of iodine for preschool children, $120 \mu \mathrm{g}$ for schoolchildren, $150 \mu \mathrm{g}$ for adolescents and adults, and $200 \mu \mathrm{g}$ for pregnant and lactating women [11]. WHO recommended Universal Salt Iodization (USI) for elimination of IDDs [11] a daily intake of salt by all members of the population should provide the required amount of iodine [12].

Salt iodine testing is an important process indicator for monitoring progress towards Universal Salt Iodization (USI) [13]. WHO/UNICEF/ICCIDD recommends that the salt iodine content at the packaging level must be 50$60 \mathrm{ppm}$ and 20-30 ppm at the retail shops, to achieve at least $15 \mathrm{ppm}$ in the household dietary consumption [2]. The salt iodine content is estimated by rapid test kit(RTK) methods which measures of the iodine content [11].

Iodization of salt is currently carried out following the USI initiative $[14,15]$. The concentration of iodine from iodized salt can be influenced by the variability of iodine during iodization process, packing with bags and instability of iodine in the salt. Moreover, moisture content of salt, humidity, light, heat, impurities in salt, alkalinity or acidity, and the form in which the iodine is present, affect iodine stability in salt [16].

Recent monitoring of the iodine indicated that $62 \%$ of households used adequately iodized salt containing at least 15 ppm iodine in Laelay Maychew District, Northern Ethiopia and South Africa [17-19], considerably below the international goal of $90 \%$ coverage [11].

According to the Ethiopia Demography and Health Survey 2016, 89\% of the Ethiopian population uses iodized salt [20]. Measuring iodine concentrations and documentation of losses at the consumers' level are essential elements of a programme to eliminate iodine deficiencies. Additionally, it is important to monitor what percentage of the population remains at risk of insufficient intake of iodine. Therefore, this study aimed to investigate the adequacy of iodine from dietary salt at household level.

\section{Methods}

\section{Study design and area}

A Community-based, cross-sectional study design was carried out from January 18-30, 2017 in Dessie and Combolcha towns. Dessie is the capital city of South Wollo administrative Zone, and is one of the three metropolitan towns in the Amhara Regional State. It is located in the Northern part of Ethiopia about $401 \mathrm{Kms}$ from the capital city, Addis Ababa to the North East, and about $480 \mathrm{Kms}$ away from the capital city of the Amhara Regional State, Bahir-Dar, to the east. According to the 2013-2014 years, the total population in the town is 195,661 (male 94,285, female 101,376).
Combolcha town is also $374 \mathrm{kms}$ far away from Addis Ababa and it is one of the industrial zones in the nation. Administratively Combolcha is structured in 11 Administrative Units (called Kebeles in Amharic). The town has relatively hot climatic condtion as compared to Dessie. According to 2015/16, the total households are 30, 631, in which 23, 102 (75.4\%) households are living in urban areas and 7, 529 households are residing in rural areas. Housewives or household heads that had been living for at least 6 months and above in the randomly selected Kebeles were included in the study. Severely ill individuals and those who cannot prepare foods in their home were excluded from the study.

Sample size was determined using single population proportion formula by considering the prevalence of insufficient iodine intake at household level in Tigray a nearby region in Ethiopia as 63\% [20], 95\% confidence level based on standard normal distribution, $5 \%$ as degree of precision and 1.5 as design effect. Assuming 5\% for non-respondent, the sample size was 524 households.

Multistage sampling technique was used to select target respondents. Dessie city administration has ten administrative units (Kebeles) and Combolcha town has five administrative units (Kebeles). Then three Kebeles from Dessie town and one Kebele from Combolcha town were selected randomly. The sample was allocated proportionally to the size of households in the two areas. The allocated sample for Dessie town was reallocated to the three Kebeles based on the total households resided. The total households in the selected Kebeles of the two Towns were divided to the allocated sample sizes to get the sampling interval and the study subjects were systematically drawn.

\section{Data measurement and quality control}

All required data were assembled using a questionnaire organized from EDHS, UNICEF procedure protocol and from other studies $[11,20,21]$ via Open Data Kit (ODK) tool. The questionnaire was compiled from validated pre-established sources and was modified contextually as per the objectives of the study [2, 10, 19-22]. Six data collectors who had Bachelor of Science (BSc) in medical laboratory technicians with previous data collection experiences, were recruited. Additionally, two Master of Public Health (MPH) professionals with previous experiences in handling survey field work were selected as supervisors.

Before the commencement of actual survey, pre-test was conducted on $5 \%$ of the sample in areas found other than the study site. Detailed investigation was carried out to shuffle the tool in order to address the desired study objective. A 3 days intensive training was given for data collectors and supervisors on how to record, compile and complete the questionnaire. The RTK was done under close supervision and if there is any suspicion the test was repeated. 
Determination of iodine content from dietary salt by using RTK, socio-demographic, economic variables, sources of iodized salt, knowledge about iodine and its effect, common food sources, container/shelf of iodized salt, timing of addition during cooking and other associated factors were obtained by interview using smart phones.

One medium sized tea spoon of iodized salt was taken from each households. The semi-quantitative estimation of the salt iodine by using a RTK is based on the reaction between starch and iodine to form starch-iodine complex. This test solution contains an acidic buffer and a reducing agent, which convert potassium iodate $\left(\mathrm{KIO}_{3}\right)$ to elemental iodine $\left(\mathrm{I}_{2}\right)[11]$.

The white cup found from the test kit was filled with salt and spread the salt surface flat first. Secondly, two drops of the test solution on the surface of the salt were added and the colour of the test sample is compared with the standard colour chart $(<15 \mathrm{ppm}$ or $>15 \mathrm{ppm})$ $[13,16]$, within $1 \mathrm{~min}$ and iodine content was determined. If the colour of test sample did not appear after $1 \mathrm{~min}$, three to five drops of the recheck solution were added on a fresh sample, followed by two drops of test solution were added on the same spot and then the colour was compared with the colour chart to record the content (recorded as "adequate" for blue colour, as "Low" for gray colour and as "nil/zero" for white colour).

\section{Data management and analysis}

The data collected by ODK software were uploaded to cloud server of the user account. Once the data had been collected and stored, it was downloaded in the form of comma delimited file type. Then, it was finally transported to STATA version 12 for analysis. The data were explored for missing data, distribution of outcome variable, and test of parallel lines and model fitness information.

The association between the adequacy of iodized salt and related factors was performed through ordinal logistic regression. The main effect was specified for the location of the proportional odds model, test of parallel lines checked $(p$-value $=0.34)$, Goodness of fit statistics was checked $(P$-value $=0.67)$ and the Link function was Logit during the analysis. Candidate variables with $p$-value $<0.2$ moved to the final model to identify predictor variables and finally, a $p$-value of < 0.05 (two-tailed) was used to declare statistically significant variables.

Socio-economic status of the households was measured using assets by Principal Component analysis. After check the assumption of sample adequacy, communality and presences of complex struction, the score was ranked from the first (poorest) to fifth (richest) quintile (constituting $20 \%$ of distribution in each category).

\section{Results}

Socio-demographic and economic characteristics

A total of 500 households in Dessie and Combolcha Towns gave complete responses on adequacy of iodized salt. About three-fourth of the households (77.4\%) were from Dessie Town residents and the remaining were from Combolcha (Table 1). The mean age of respondents was 33 years ( \pm 10.5 standard deviation). Among all respondents, about $91 \%$ of the household members who involved in the preparation of food were women. Of all study participants, about $78 \%$ respondents were married.

\section{Respondents' information regarding iodine}

In this study, about one-fifth of the participants had not heard about iodine. Among study subjects who heard about iodine, more than half of them obtained information from mass media (television and radio) about iodine. Three fourth of the respondents believed that deficiency of iodine brings development of goiter only. More than $80 \%$ of respondents replied that iodine deficiency disorder is preventable. Regarding the dietary sources of iodine, $25 \%$ of the study participants knew the food sources that contain iodine (Table 2).

Regarding the place of storage of iodized salt, almost all households placed it in a dry place. The majority of the participants (96.4\%) reported that the salt kept under cover, but $26.2 \%$ of the respondents exposed for sunlight before storage. Regarding the use of salt, $80.6 \%$ of the participants stated that they added the salt at the end of cooking while $15.6 \%$ of them added at the middle of cooking.

\section{Adequacy of iodized salt}

Household dietary salt was determined by using rapid test kit duringthe data collection period. Among all respondents,18\% (95\% CI: 14.8-21.2\%) of the households used salt without iodine (zero iodine concentration) and 13.2\% (95\% CI: 10.1-16.1\%) of the respondents used salt with inadequately iodized (below $15 \mathrm{ppm}$ ) whereas, $68.8 \%$ (95\% CI: $64.8-72.9 \%$ ) of the salt sample was adequately iodized. Area specific iodized salt consumption, the report revealed that about $62 \%$ of the respondents of Combolcha residents used salt with zero iodine contents while $22.3 \%$ of households of Dessie town used inadequately iodized salt. The highest percentage of no iodine content was observed among farmer respondents (21.1\%) followed by respondents from housewives (19.4\%) and the least was found from government employees (9.6\%). In salts bought from open market, 54\% was not iodized (Figs. 1 and 2).

\section{Factors related with adequacy of iodized salt at household level}

Among variables entered to ordinal logistic model, area of residents (Dessie vs Combolcha), socio-economic status, site for labeling and packing of iodized salt and 
Table 1 Showed Socio-Demographic characteristics of households from Dessie and Combolcha Town residents, June 2017

\begin{tabular}{|c|c|c|}
\hline Variables $(n=500)$ & Frequency & Percent \\
\hline \multicolumn{3}{|l|}{ Residents } \\
\hline Dessie & 387 & 77.4 \\
\hline Combolcha & 113 & 22.6 \\
\hline \multicolumn{3}{|l|}{ Sex of respondents } \\
\hline Female & 475 & 95.0 \\
\hline Male & 25 & 5.0 \\
\hline \multicolumn{3}{|c|}{ Household involved in food preparation } \\
\hline Wife & 457 & 91.0 \\
\hline Husbands & 43 & 9.0 \\
\hline \multicolumn{3}{|l|}{ Age of respondents(in years) } \\
\hline$\leq 25$ years & 148 & 29.6 \\
\hline $26-34$ years & 142 & 28.4 \\
\hline$\geq 35$ years & 210 & 42.0 \\
\hline \multicolumn{3}{|l|}{ Respondents educational Status } \\
\hline Formal & 338 & 67.6 \\
\hline Informal & 162 & 32.4 \\
\hline \multicolumn{3}{|l|}{ Religion } \\
\hline Muslim & 267 & 53.4 \\
\hline Orthodox & 217 & 43.4 \\
\hline Others & 16 & 3.2 \\
\hline \multicolumn{3}{|l|}{ Marital status of the respondents } \\
\hline Married & 391 & 78.2 \\
\hline Single & 109 & 21.8 \\
\hline \multicolumn{3}{|l|}{ Respondents occupational status } \\
\hline Housewife & 339 & 67.8 \\
\hline Farmer & 79 & 15.8 \\
\hline Private employee & 46 & 9.2 \\
\hline Government employee & 36 & 7.2 \\
\hline \multicolumn{3}{|l|}{ Households' wealth Status } \\
\hline First quintile & 106 & 21.2 \\
\hline Second quintile & 78 & 15.6 \\
\hline Third quintile & 108 & 21.6 \\
\hline Fourth quintile & 115 & 23.0 \\
\hline Fifth quintile & 93 & 18.6 \\
\hline \multicolumn{3}{|c|}{ Role of respondents regarding with food } \\
\hline Preparation only & 106 & 21.2 \\
\hline Preparation and recruitments & 394 & 78.8 \\
\hline
\end{tabular}

exposure of iodized salt for sunlight were found to have significant association with the adequacy of iodized salt at household levels. The odds of iodized salt adequacy among Dessie residents were almost three times higher as compared to the Odds of iodized salt adequacy among Combolcha Residents (OR=2.53; 95\% CI: 1.31-4.90). Moreover, The probability of adequacy of iodized salt decreased by $90 \%$ if open market salt was used. $(\mathrm{OR}=0.10$; 95\% CI: 0.04-0.23) (Table 3). However, independent variables like marital status of the respondent, Educational status of the respondent and occupational status of the respondents did not show statistically significant association with adequacy of iodized salt.

\section{Discussion}

The study found that the overall percentage of households who used inadequate iodized salt $(<15 \mathrm{ppm})$ was $31.2 \%$. The iodized salt inadequacy was more severe in Combolcha residents. The finding of this study revealed that adequacy of iodized salt was much higher than reports from rural community of Maychew (33\%) [21], West Ethiopia (8.7\%) [22] and Gondar town, Ethiopia (28.9\%) [23] and Asella Town, Ethiopia (62.9\%) [24]; and similar result was observed from urban area of Sidama Zone, Ethiopia (65\%) [25]. Even though there are many variation and strategies across countries, the finding of the study was also higher as compared to findings from other low income contries $[13,26]$. In contrast to the above finding, adequacy of iodized salt in the study was lower than findings from EasternNepal (82.6\%) [27] and Telangana, India (79\%) [3].

The reason for these variations may be due to relatively wide time elapsed between the current study and others. Additionally, controlling of iodine deficiency disorders has been given universal attention with strong monitoring and evaluation of iodine from dietary salt at every levels (at production, transportation and consumption levels). The differences in agro-ecological situations, socio-economic status and perceived knowledge and practices among households may bring the above discrepancies in different areas.

Proportional Odds model with Logit link function was used to identify predictors of iodized salt adequacy at household level. The model identified place of residence, households in the fourth quintile of socio-economic class, packing and labeling site and exposure for sunlight as having statistical significant association with adequacy of iodized salt at consumption level. The salt samples brought from Dessie household residents were found to be more likely adequately iodized as compared to salt samples from Combolcha Town. This report was in line with the WHO recommendation report [2], finding from studies conducted in West Ethiopia [22], Eastern Nepal [27] and Telangana, India [3] indicated that the level of moisture and humidity of areas affect the content of iodine in the salt. Additional reasons may be most of the households of Combolcha Town used open market salt for cooking and they exposed the salt to sunlight. 
Table 2 Participants' information regarding iodine health importance and its deficiency in Dessie and Combolcha residents, June 2017

\begin{tabular}{|c|c|c|}
\hline Items & Frequency & Perce \\
\hline \multicolumn{3}{|l|}{ Have ever heard about lodine? } \\
\hline Yes & 403 & 80.6 \\
\hline No & 97 & 19.4 \\
\hline \multicolumn{3}{|l|}{ Sources of information for iodine } \\
\hline From friends and relatives only & 22 & 5.5 \\
\hline From Health Extension Workers only & 140 & 34.7 \\
\hline From Television only & 142 & 35.2 \\
\hline From Health extension workers and Television & 99 & 24.6 \\
\hline \multicolumn{3}{|l|}{ Respondents response on the effect of IDD $(n=403)$} \\
\hline Goiter only & 303 & 75.2 \\
\hline Goiter, abortion, mental retardation and cretinism & 77 & 19.2 \\
\hline cancer & 1 & 0.2 \\
\hline anemia & 1 & 0.2 \\
\hline Did not know & 21 & 5.2 \\
\hline \multicolumn{3}{|l|}{ Do you know Goiter? } \\
\hline Yes & 461 & 92.2 \\
\hline No & 39 & 7.8 \\
\hline \multicolumn{3}{|l|}{ Causes of goiter } \\
\hline lodine deficiency & 364 & 72.8 \\
\hline Hereditary & 42 & 8.4 \\
\hline Evil & 21 & 4.0 \\
\hline Infection & 70 & 14.0 \\
\hline Poisoning & 24 & 4.8 \\
\hline \multicolumn{3}{|l|}{ Is IDD preventable? } \\
\hline Yes & 417 & 83.4 \\
\hline No & 83 & 16.6 \\
\hline \multicolumn{3}{|l|}{ Know dietary sources of iodine } \\
\hline Yes & 126 & 25.2 \\
\hline No & 358 & 71.6 \\
\hline Not sure & 16 & 3.2 \\
\hline \multicolumn{3}{|l|}{ Do you buy iodized salt? } \\
\hline Yes & 394 & 78.8 \\
\hline No & 106 & 21.2 \\
\hline \multicolumn{3}{|l|}{ Site of production (package place) } \\
\hline Afdera & 136 & 27.2 \\
\hline Mesobo & 56 & 11.2 \\
\hline Open & 125 & 25.0 \\
\hline Shewit & 183 & 36.6 \\
\hline \multicolumn{3}{|l|}{ Reason for buying iodide salt } \\
\hline Good for health only & $347(69.4)$ & 69.4 \\
\hline Advice from health professional & $31(6.2)$ & 6.2 \\
\hline Has no option & $32(6.4)$ & 6.4 \\
\hline
\end{tabular}

Table 2 Participants' information regarding iodine health importance and its deficiency in Dessie and Combolcha residents, June 2017 (Continued)

\begin{tabular}{lll}
\hline Items & Frequency & Percent \\
\hline Did not buy & $90(18.0)$ & 18.0 \\
Types of pack & & \\
Packed & $395(79.0)$ & 79.0 \\
Unpacked & $105(21.0)$ & 21.0 \\
Do you know the benefits of iodized salt? & & \\
Yes & $392(78.4)$ & 78.4 \\
No & $108(21.6)$ & 21.6 \\
Benefit of iodized salt (n=392) & & \\
Has good taste and palatability & $113(28.8)$ & 28.8 \\
Prevent goiter and other IDDs & $279(71.2)$ & 71.2 \\
Preference for salt & & \\
lodized & $402(80.4)$ & 80.4 \\
Non-iodized & $32(6.4)$ & 6.4 \\
No preference & $66(13.2)$ & 13.2 \\
\hline
\end{tabular}

Households found in higher socio-economic categories showed more significant observed difference in better adequacy of iodized salt use as compared to households found in low socio-economic status. Many studies agreed that iodized salt was not accessible for most of the poor society in the world. Reports from Asella town [24], Sidama Zone [25] and rural India [26] postulated that the better socio-economic status, the more adequately iodized salt used and agreed that packed iodized salt is not affordable for the poor.

Regarding place of iodized salt where it was packed and labeled; households who used open market salt were less likely to use adequately iodized salt. Study conducted by Kumar A., et al. in Eastern Nepal [27] found that there is a significant association between use of open market salt and inadequacy of iodine content in dietary salt. Similarly studies from West Ethiopia [22], Sidama, SouthernEthiopia [25], Gondar, Ethiopia [23] and Telangana, India [3] stated that the use of packed salt has positive association with increased contents of iodine. Open market salt is more prone to evaporation and iodine by its nature is highly volatile.

This study revealed that the odds of having adequate iodine concentration by households who did not expose for sunlight were about three times higher than the odds of iodized salt used by households who exposed it for sunlight. Studies from Gondar, Ethiopia [23], India [13] and London confirmed that heat can contribute the highest share for iodine loss. Sunlight exposure hastens the oxidation of iodide to elemental iodine and this is highly unstable. 

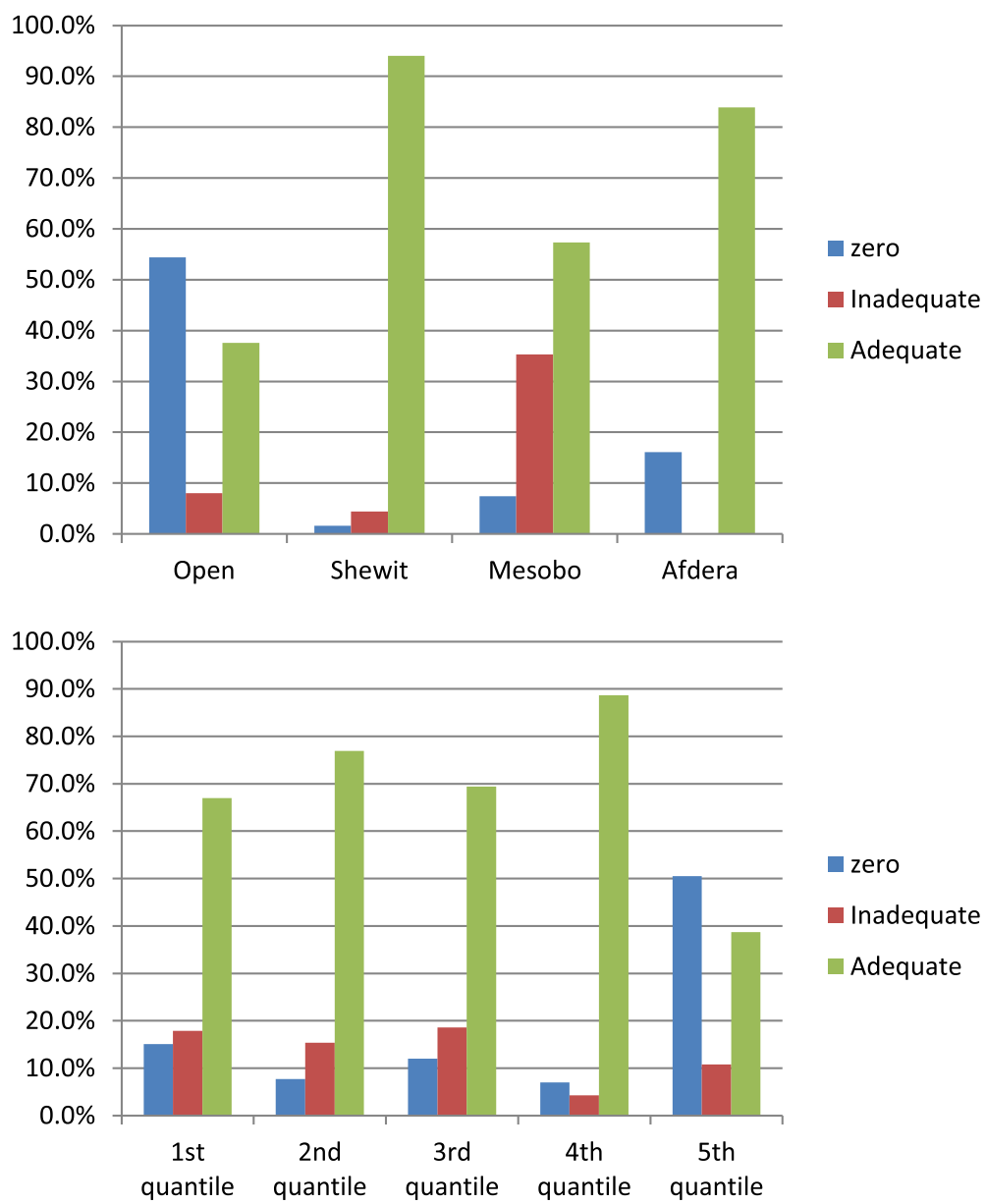

Fig. 1 Consumption of iodized salt at household level by the site for packing and labeling of salt in Dessie and Combolcha Town, 2017

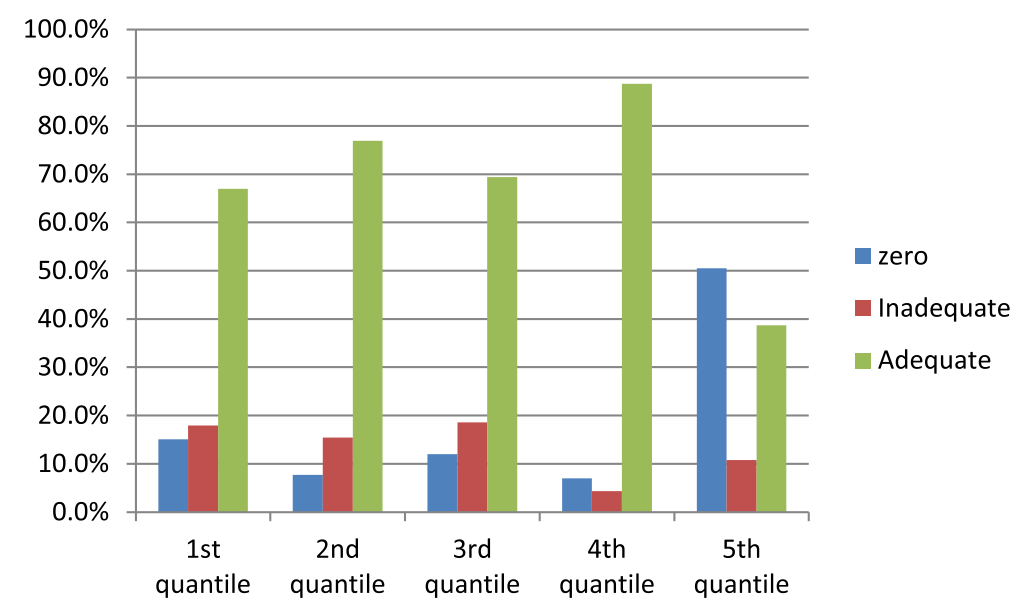

Fig. 2 Consumption of iodized salt at household level by their socio-economic statusin Dessie and Combolcha Town, 2017 
Table 3 Factors related with lodized salt adequacy at household level among Dessie and Combolcha Town residents in May 2017

\begin{tabular}{|c|c|c|c|c|c|}
\hline \multirow[t]{2}{*}{ Variables } & \multicolumn{3}{|c|}{ Test result of lodine by RTK } & \multirow[t]{2}{*}{ COR $(95 \% \mathrm{Cl})$} & \multirow[t]{2}{*}{ AOR $(95 \% \mathrm{Cl})$} \\
\hline & $\begin{array}{l}\text { Nil } \\
\text { N (\%) }\end{array}$ & $\begin{array}{l}\text { Inadequate } \\
\mathrm{N}(\%)\end{array}$ & $\begin{array}{l}\text { Adequate } \\
\mathrm{N}(\%)\end{array}$ & & \\
\hline \multicolumn{6}{|l|}{ Place of residence } \\
\hline Dessie & 20 & 66 & 301 & $10.91(6.68-16.44)$ & $2.53(1.31-4.90)$ \\
\hline Combolcha & 65 & 8 & 40 & 1 & 1 \\
\hline \multicolumn{6}{|c|}{ Marital status of the respondent } \\
\hline Married & 68 & 46 & 277 & $2.07(0.89-4.85)$ & $0.92(0.55-1.55)$ \\
\hline Single & 22 & 20 & 67 & 1 & 1 \\
\hline \multicolumn{6}{|c|}{ Educational status of respondents } \\
\hline Formal & 43 & 48 & 243 & $1.91(1.29-2.80)$ & $1.79(0.97-3.28)$ \\
\hline Informal & 47 & 18 & 101 & 1 & 1 \\
\hline \multicolumn{6}{|l|}{ Occupational status } \\
\hline Farmer & 16 & 8 & 55 & $1.05(0.63-1.76)$ & $1.16(0.68-1.97)$ \\
\hline Employed & 8 & 15 & 59 & $1.32(0.78-2.27)$ & $1.37(0.80-2.35)$ \\
\hline Housewife & 66 & 43 & 230 & 1 & 1 \\
\hline \multicolumn{6}{|l|}{ Socioeconomic status } \\
\hline First quintile (poorest) & 16 & 19 & 71 & $4.18(2.38-7.31)$ & $1.66(0.85-3.25)$ \\
\hline Second quintile & 6 & 12 & 60 & $6.96(3.60-13.46)$ & $2.05(0.93-4.51)$ \\
\hline Third quintile & 13 & 20 & 75 & $4.76(2.72-8.41)$ & $1.90(0.96-3.75)$ \\
\hline Fourth quintile & 8 & 5 & 102 & $15.33(7.69-30.57)$ & $2.54(1.10-5.87)$ \\
\hline Fifth quintile(Richest) & 47 & 10 & 36 & 1 & 1 \\
\hline \multicolumn{6}{|c|}{ Site for labeling and packing of iodized salt } \\
\hline Open market & 68 & 10 & 47 & $0.08(0.04-0.19)$ & $0.10(0.04-0.23)$ \\
\hline Shewit & 3 & 8 & 172 & $3.38(1.35-8.50)$ & $1.25(0.92-3.49)$ \\
\hline Mesobo & 10 & 48 & 78 & $0.36(0.17-0.77)$ & $0.18(0.08-0.43)$ \\
\hline Afdera & 8 & 4 & 44 & 1 & 1 \\
\hline \multicolumn{6}{|c|}{ lodized salt exposure for sunlight } \\
\hline No & 18 & 59 & 292 & $9.21(5.99-14.01)$ & $2.54(1.31-4.91)$ \\
\hline Yes & 72 & 7 & 52 & & 1 \\
\hline
\end{tabular}

The percentage of adequately iodized salt $(68.8 \%)$ is not a warranty to conclude that utilization of iodine is sufficient unless we determine urinary iodine concentration of households in the study area. Due to the relatively small sample size and the winter season of data collection period, the finding of the study may not strong enough to represent the general population.

\section{Conclusions}

In conclusion, availability of adequately iodized salt in Dessie and Combolcha towns was $68.8 \%$. As compared to the targets of WHO recommendation and the Ethiopian- Federal Ministry of Health, the progress in the study area remaines slow. Only $25 \%$ of the households knew the benefit of iodized salt and most of them did not know negative effect of sunlight exposure.
The level of humidity, socio-economic status, use of iodized salt which is packed and did not expose to sunlight had significant association with adequacy of iodized salt. Working at grass root level is vital to achieve the desired target; to internalize the consequences of iodine deficiencies and proper utilization of iodized salt by enhancing the knowledge of individuals about the role of iodine and benefit of iodized salt. There should be periodical monitoring and evaluation of iodine particularly in areas where the use of open salt is common. Educating the households regarding proper practices of iodized salt use should be extensively addressed like not to expose for heat, adding salt at the end of cooking, placing in dry place and proper storage of salt in the house. There should be also regular and strick monitoring schedule at household level to take an immediate action. 


\section{Abbreviations}

ICCIDD: International Consultancy Committee for lodine Deficiency Disorder; IDD: Iodine Deficiency Disorder; ODK: Open Data Kit; OR: Odds Ratio; PPM: Parts Per million; RTK: Rapid Test Kit; UIC: Urinary lodine Concentration; USI: Universal Salt lodization

\section{Acknowledgements}

We would like to acknowledge Wollo University for providing materials used for the work. Our deepest gratitude goes to data collectors, kebeles leaders and supervisors. The last but not the least, our heartfelt thanks goes to Dessie and Combolcha towns residents particularly the respondents.

\section{Funding}

Wollo University was the sponsor of the study project. The funders had no role in study design, data collection and analysis, decision to publish, or preparation of the manuscript.

\section{Availability of data and materials}

The datasets during and/or analyzed during the current study is available from the corresponding author on reasonable request.

\section{Authors' contributions}

TCM: initiated and developed the proposal, did the data collection and analysis and wrote the manuscript. SE: developed the proposal, revised the report and involved in the revision of manuscript. YW: involved in the proposal organization, supervise the field work, worked on the analysis and wrote up the manuscript. MA: worked on the analysis and wrote up the manuscript. NC: worked on the analysis and wrote up the manuscript. All authors have read and approved the manuscript.

\section{Authors' information}

TCM: MPH in Human Nutrition, works at deparment of Public Healt, College of Medicine and Health Sciences, Wolllo University, Ethiopia. SE: MPH in Human Nutrition, works at deparment of Public Healt, College of Medicine and Health Sciences, Wolllo University, Ethiopia. YW: PhD Fellow in Health Education and promotion at Jimma University, works at deparment of Public Healt, College of Medicine and Health Sciences, Wolllo University, Ethiopia. MA: MPH in Reproductive Health, works at deparment of Public Healt College of Medicine and Health Sciences, Wolllo University, Ethiopia. NC: $\mathrm{MPH}$ in Reproductive Health, works at deparment of Public Healt, College of Medicine and Health Sciences, Wolllo University, Ethiopia.

\section{Ethics approval and consent to participate}

Letter of ethical clearance was obtained from Wollo University College of Medicine and Health Sciences, Institutional Health Research Ethics Review Committee. Written informed consent was obtained from each participant, and confidentiality was maintained by giving codes for respondents. Data collectors informed the clients that they have full right to discontinue or refuse to participate in the study.

\section{Consent to publication}

Not applicable.

\section{Competing interests}

The authors declare that they have no competing interests.

\section{Publisher's Note}

Springer Nature remains neutral with regard to jurisdictional claims in published maps and institutional affiliations.

\section{Author details}

'Human Nutrition Unit, Department of Public Health, Wollo University, Dessie, Ethiopia. ${ }^{2}$ Department Public Health, Wollo University, Dessie, Ethiopia. ${ }^{3}$ Reproductive Health Unit, Department of Public Health, College of Medicine and Health Sciences, Wollo University, Dessie, Ethiopia.
Received: 9 March 2018 Accepted: 24 September 2018

Published online: 03 October 2018

\section{References}

1. Trerotoli P, Ciampolillo A, Marinelli G, Giorgino R, Serio G. Prevalence of thyroid nodules in an occupationally radiation exposed group: a cross sectional study in an area with mild iodine deficiency. BMC Public Health. 2005;5(1):73.

2. WHO, ICCIDD, UNICEF. Assessment of iodine deficiency disorders and monitoring their elimination a guide for programme managers, Second edition. 2008.

3. Zimmermann MB. The effects of iodine deficiency in pregnancy and infancy. Paediatr Perinat Epidemiol. 2012;1:108-17. https://doi.org/10.1111/j. 1365-3016.2012.01275.x.

4. WHO. lodine status worldwide: WHO Global Database on lodine Deficiency, Department of Nutrition for Health and Development World Health Organization, Geneva: 2004.

5. Andersson $M$, Karumbunathan $V$, Zimmermann MB. Global iodine status in 2011 and trends over the past decade. J Nutr. 2012;142(4):744-50. https://doi.org/10.3945/jn.111.149393. Epub 2012 Feb 29.

6. F. DELANGE. The Disorders Induced by lodine Deficiency Thyroid. Jan. 1994; 4:107. Accessed at: https://doi.org/10.1089/thy.1994.4.107.

7. Embiez Îd. Colloque International Sur Les Cyanobactéries Pour La Santé, La Science Et Le Developpement: International Symposium On Cyanobacteria For Health, Science And Development. 2004.

8. De Benoist B, McLean E, Andersson M, Rogers L. lodine deficiency in 2007: global progress since 2003. Food Nutr Bull. 2008;29(3):195-202.

9. Zimmermann MB, Connolly K, Bozo M, Bridson J, Rohner F, Grimci L. lodine supplementation improves cognition in iodine-deficient schoolchildren in Albania: a randomized, controlled, double-blind study. Am J Clin Nutr. 2006;83(1):108-14

10. Government of the Federal Democratic Republic of Ethiopia:Assessment of Feasibility and Potential Benefits of Food Fortification in Ethiopia, Federal Ministry of Health; 2011

11. World Health Organization, UNICEF, ICCIDD, Assessment of iodine defi ciency disorders and monitoring their elimination; A Guide For Programme Managers, Third edition. 2007.

12. Rohner F, Zimmermann $M$, Jooste $P$, et al. Biomarkers of nutrition for development-iodine review. J Nutr. 2014;144(8):1322S-42S. https://doi. org/10.3945/jn.113.181974

13. Kshatri J, Karmee N, Madhab Tripathy R. Prevalence and Predictors of Poor lodine Nutrition in Rural South Odisha: A Comparative Study between Coastal and Hilly Districts. Natl J Community Med. 2017;8.

14. Sharma D, Despande AV, Ahmad N, Gupta A, Nafees S. Monitoring and estimation of iodine content of edible salt in urban areas of Meerut district, after four decades of universal salt iodization. Int J Biomed Adv Res. 2014;05(02):94.

15. Kshatri JS, Karmee N, Tripathy RM. Prevalence and predictors of poor iodine nutrition in rural South Odisha: a comparative study between coastal and hilly districts. Ntl J Community Med. 2017:8(1):41-6.

16. Ranganathan S, Karmarkar MG, Krupadanam M, Brahmam GN, Rao MV, Vijayaraghavan K, Sivakumar B. Stability of iodine in salt fortified with iodine and iron. Food Nutr Bull. 2007;28(1):109-15.

17. Jooste PL, Weight MJ, Lombard CJ. lodine concentration in household salt in South Africa. Bull World Health Organ. 2001;79(6):534-40.

18. Shawel D, Hagos S, Lachat CK, Kimanya ME, Kolsteren P. Post-production losses in iodine concentration of salt hamper the control of iodine deficiency disorders: a case study in northern Ethiopia. J Health Popul Nutr. 2010;28(3):238-44.

19. Gidey B, Alemu K, Atnafu A, Kifle M, Tefera Y, et al. Availability of adequate iodized salt at household level and associated factors in rural communities of Laelay Maychew District, northern Ethiopia: a cross sectional study. J Nutr Health Sci. 2015;2(1):103. https://doi.org/10.15744/2393-9060.1.403.

20. Central Statistical Agency, Ethiopia Demographic and Health Survey, Addis Ababa, Ethiopia ICF International Calverton, Maryland, USA 2016.

21. Meselech Regassa D, Tsedeke Wolde H, Befirdu Mulatu J. Utilization of adequately iodized salt on prevention of iodine deficiency disorders at household level and associated factors in Lalo Assabi District, West Ethiopia. J Nutr Food Sci. 2016;6:471. https://doi.org/10.4172/2155-9600.1000471.

22. Hailay Gebrearegawi Gebremariam, Melkie Edris Yesuf, and Digsu Negese Koye, "Availability of Adequately lodized Salt at Household Level and 
Associated Factors in Gondar Town, Northwest Ethiopia," ISRN Public Health. 2013;2013(160582):6. https://doi.org/10.1155/2013/160582.

23. Roy R, Chaturvedi M, Agrawal D, Ali H. Household use of iodized salt in rural area. J Fam Med Prim Care. 2016;5(1):77-81. https://doi.org/10.4103/22494863.184628.

24. Masresha Tsegaye, Dejene Hailu, Menen Zegeye, Availability and Utilization of Adequately lodized Salt by Urban and Rural Households and Associated Factors in Southern Ethiopia, Sidama Zone, Bensa Woreda: A Comparative Cross-sectional Study. Intl J Food Sci Nutr Engin. 2016;6(3):62-71. https://doi. org/10.5923/j.food.20160603.03.

25. Ashwini Kumar Nepal PRS, Gelal B, Lamsal M, Brodie DA, Baral N. Household salt iodine content estimation with the use of rapid test kits and lodometric titration methods. J Clin Diagn Res [serial online]. 2013;7(5):892-5.

26. Hawas SB, Lemma S, Mengesha ST, Demissie HF, Segni MT. Proper utilization of Adequatly iodized salt at house hold level and associated Factores in Asella town Arsi zone Ethiopia: a community based cross sectional study. J Food Process Technol. 2016;7:573. https://doi.org/10.4172/ 2157-7110.1000573.

27. Wirth JP, Leyvraz M, Sodani PR, Aaron GJ, Sharma ND, Woodruff BA. Coverage of adequately iodized salt is suboptimal and Rice fortification using public distribution channels could reach low-income households: findings from a cross-sectional survey of Anganwadi center catchment areas in Telangana, India. PLoS One. 2016;11(7):e0158554. https://doi.org/10. 1371/journal.pone.0158554

Ready to submit your research? Choose BMC and benefit from:

- fast, convenient online submission

- thorough peer review by experienced researchers in your field

- rapid publication on acceptance

- support for research data, including large and complex data types

- gold Open Access which fosters wider collaboration and increased citations

- maximum visibility for your research: over $100 \mathrm{M}$ website views per year

At $\mathrm{BMC}$, research is always in progress.

Learn more biomedcentral.com/submissions 